\title{
JURNAL \\ KEDOKTERAN DAN KESEHATAN \\ Faktor Dominan Obesitas pada Siswa Sekolah Menengah Atas di Tangerang Selatan Indonesia
}

\author{
Sugiatmi $^{1}$, Dian Rini Handayani ${ }^{2}$ \\ ${ }^{1}$ Fakultas Kesehatan Masyarakat, Universitas Indonesia \\ ${ }^{1,2}$ Program Studi Kesehatan Masyarakat, Fakultas Kedokteran dan Kesehatan, Universitas \\ Muhammadiyah Jakarta \\ Jl. KH. Ahmad Dahlan, Cirendeu, Ciputat, Tangerang Selatan, Indonesia \\ Email: sugiatmi@umj.ac.id
}

\begin{abstract}
ABSTRAK
Penyakit degeneratif atau penyakit non infeksi merupakan salah satu implikasi kesehatan yang dapat terjadi kepada seseorang di masa depan sebagai akibat dari perilaku kesehatan di masa remaja. Oleh karena itu, sangat penting mengidentifikasi faktor penentu obesitas agar dapat diketahui upaya pencegahannya pada remaja. Penelitian ini betujuan untuk mengetahui faktor penentu obesitas di kalangan siswa SMA di Tangerang Selatan. Data diperoleh dari survei cross sectional yang dilakukan di SMAN 7 Tangerang Selatan terhadap 131 siswa SMA yang dipilih dengan teknik sampling proportional stratified sampling. Responden dinilai obesitas jika Z-score IMT/U $\left(\mathrm{kg} / \mathrm{m}^{2}\right)$ lebih dari 2 standar deviasi dari standar acuan pertumbuhan. Analisis bivariat menggunakan uji chi square. Regresi logistik ganda digunakan untuk menganalisis faktor penentu obesitas. Hasil penelitian ini menunjukkan risiko obesitas lebih tinggi pada siswa yang memiliki aktivitas fisik rendah $(\mathrm{OR}=2.39)$, rendahnya pengetahuan gizi $(\mathrm{OR}=2.89)$, dan tingginya konsumsi makanan cepat saji $(\mathrm{OR}=2.74)$. Penentu obesitas adalah pengetahuan gizi dan frekuensi konsumsi makanan cepat saji. Risiko tertinggi adalah di kalangan siswa yang memiliki pengetahuan gizi rendah. Sekolah sebaiknya melakukan pelatihan tentang gizi dan makanan sehat secara teratur kepada siswa serta mengintegrasikan pengetahuan gizi ke dalam kurikulum sekolah untuk meningkatkan pengetahuan gizi siswa.
\end{abstract}

Kata kunci: obesitas, remaja, pengetahuan

\section{Determinant of Obesity among Senior High School Student at South Tangerang Indonesia}

\begin{abstract}
Degenerative disease or non-infectious disease is one of the health implications that can occur to a person in the future as a result of health behavior in adolescence. Therefore, it is very important to identify the determinants of obesity in order to know prevention efforts in adolescents. This study aim to find out the determinants of obesity among high school students in South Tangerang. Data were obtain from a cross sectional survey conducted at SMAN 7 Tangerang Selatan towards 131 high school students selected by stratified proportional sampling technique. Respondents were considered obesity if Z-score IMT/U $\left(\mathrm{kg} / \mathrm{m}^{2}\right)$ more than 2 standard deviations from the growth reference standard. Bivariate analysis using chi square test. Multiple logistic regression was used to analyze the determinant factor of obesity. The results of this study indicate higher risk of obesity in students with low physical activity $(\mathrm{OR}=2.39)$, low of nutritional knowledge $(\mathrm{OR}=2.89)$, and high consumption of fast food $(\mathrm{OR}=2.74)$. Determinant of obesity are nutritional knowledge and of fast food consumption frequency. The highest risk is among students who have low nutritional knowledge. Schools should conduct regular nutrition and healthy food
\end{abstract}


training to student and integrate nutritional knowledge into the school curriculum to improve students' nutritional knowledge.

Keywords: obesity, adolescent, knowledge

\section{Pendahuluan}

Kegemukan dan obesitas didefinisikan sebagai akumulasi lemak abnormal atau berlebihan yang mendatangkan risiko bagi kesehatan. Kegemukan dan obesitas merupakan faktor risiko utama untuk sejumlah penyakit kronis, termasuk diabetes, penyakit jantung dan kanker. Masalah kegemukan dan obesitas selama ini dianggap hanya ada di negara-negara berpenghasilan tinggi, namun kini kelebihan berat badan dan obesitas meningkat di negara-negara berpenghasilan rendah dan menengah terutama di perkotaan ${ }^{1}$.

Prevalensi obesitas di seluruh dunia meningkat lebih dari dua kali lipat antara tahun 1980 dan 2014. Pada tahun 2014 lebih dari 1.9 miliar orang dewasa mulai usia 18 tahun, mengalami kelebihan berat badan dan dari jumlah tersebut lebih dari 600 juta mengalami obesitas. Secara keseluruhan, sekitar $13 \%$ dari populasi dunia kategori dewasa (11\% laki-laki dan $15 \%$ perempuan) yang mengalami obesitas pada tahun 2014 dan sekitar $39 \%$ dari orang dewasa berusia 18 tahun ke atas (38\% laki-laki dan 40\% perempuan) mengalami kegemukan ${ }^{2}$. Prevalensi obesitas di beberapa negara Asia Tenggara juga menunjukkan angka yang cukup tinggi ${ }^{3}$. Berdasarkan United Nations
Children's Fund (UNICEF) tahun 2012, Negara Indonesia menempati urutan kedua setelah Singapura dengan jumlah remaja obesitas terbesar $12.2 \%$, disusul Negara Thailand sebesar 8\%, Negara Malaysia sebesar 6\%, dan Negara Vietnam sebesar $4.6 \%{ }^{4}$.

Di Indonesia khususnya kota-kota besar, perubahan gaya hidup yang mengarah ke westernisasi dan sedentary (gaya hidup malas), mengakibatkan perubahan pola makan atau konsumsi masyarakat yang merujuk pada pola makan tinggi kalori, tinggi lemak dan kolesterol, terutama terhadap penawaran makanan siap saji (fast food) yang berdampak meningkatkan risiko obesitas $^{5}$. Prevalensi kegemukan dan obesitas usia $>18$ tahun sebesar $13.5 \%$ dan $15.4 \%$, sedangkan pada remaja usia $16-18$ tahun sebanyak $7.3 \% \quad(5.7 \%$ gemuk dan $1.6 \%$ obesitas). Provinsi dengan prevalensi gemuk tertinggi adalah DKI Jakarta (4.2\%) dan terendah Sulawesi Barat (0.6\%). Lima belas provinsi dengan prevalensi sangat gemuk diatas prevalensi nasional, yaitu Sumatera Utara, Bangka Belitung, Jawa Tengah, Sulawesi Selatan, Banten, Kalimantan Tengah, Papua, Jawa Timur, Kepulauan Riau, Gorontalo, DI Yogyakarta, Bali, Kalimantan Timur, Sulawesi Utara dan DKI Jakarta. Berdasarkan survei, prevalensi 
Sugiatmi dan Dian Rini Handayani, Faktor Dominan Obesitas pada Siswa Sekolah Menengah Atas di Tangerang Selatan Indonesia

DOI : $10.24853 /$ jkk.14.1.1-10

ini meningkat dari $1.4 \%$ pada tahun 2010 menjadi $7.3 \%$ pada tahun $2013^{6}$.

Remaja adalah usia dimana masa peralihan dari masa anak menuju dewasa dan pada masa itu merasa bertanggung jawab dan bebas dalam menentukan makannya sendiri, tidak lagi di tentukan oleh orang tua dan sebagai generasi penerus bangsa. Kurangnya pengetahuan gizi, sehingga salah dalam menentukan makanan akan berdampak pada status gizi di kemudian hari. Status gizi yang baik hanya dapat tercapai apabila didasarkan pada pola makan atas prinsip menu seimbang. Saat ini, kebiasaan makan di luar rumah menjadi suatu gaya hidup ${ }^{7}$. Di kalangan remaja perkotaan, mengkonsumsi makanan siap saji (fast food) sudah menjadi kebiasaan atau trend. Hal ini disebabkan harganya yang terjangkau oleh remaja dan promosi yang menarik $^{8}$.

Restoran siap saji (fast food) menyajikan jumlah menu makanan yang relatif banyak mengandung garam dan kadar lemak yang cukup tinggi. Sehingga, remaja yang sering mengkonsumsi makanan siap saji (fast food) akan berdampak negatif bagi remaja salah satunya mengalami kelebihan berat badan ${ }^{9}$. Remaja yang sering mengkonsumsi makanan siap saji, kemungkinan berisiko tinggi untuk mengalami obesitas dan gizi lebih yang akan berlanjut pada masa dewasa ${ }^{10}$.

Data Riskesdas 2013 menyebutkan bahwa prevalensi obesitas lebih besar pada perempuan sebesar $32.9 \%$ dan pada laki-laki sebesar 19.7\%. Selain itu, Provinsi Banten menjadi salah satu provinsi dengan tingkat prevalensi kegemukan dan obesitas tertinggi pada remaja di Indonesia ${ }^{6}$. Obesitas amat erat berkaitan dengan perilaku kesehatan yang muncul pada masa remaja seseorang, penyakit degeneratif atau penyakit non infeksi merupakan salah satu implikasi kesehatan yang dapat terjadi kepada seseorang di masa depan sebagai akibat dari perilaku kesehatan tersebut ${ }^{11}$.

Observasi awal yang telah dilakukan peneliti hasilnya terlihat banyak siswa yang mengalami kegemukan di Negara berkembang, terutama di daerah sekitar sekolah yang banyak terdapat restoran cepat saji yang menjadi tempat kesenangan siswa-siswi berkumpul saat pulang sekolah. Oleh karena itu, peneliti ingin melakukan penelitian terkait obesitas di salah satu kota yang ada di provinsi Banten yaitu Tangerang Selatan. Penelitian dilakukan di salah satu SMA dengan letak sekolah yang berada di perkotaan dan dekat dengan mall, sehingga peneliti mengasumsikan adanya kemungkinan siswa dan siswi tersebut memiliki gaya hidup yang lebih berisiko dibanding di pedesaan. Tujuan penelitian ini adalah mengetahui Faktor Dominan Obesitas pada Siswa Sekolah Menengah Atas di Tangerang Selatan. 


\section{Metode Penelitian}

Penelitian ini dilakukan di SMA Negeri 7 Tangerang Selatan dengan desain penelitian cross sectional. Populasi penelitian yaitu semua siswa kelas X, XI dan XII SMA Negeri 7 Tangerang Selatan. Sampel sebanyak 131 siswa yang dipilih berdasarkan teknik propotional stratified sampling. Kriteria inklusi pada penelitian ini yaitu berstatus sebagai siswa aktif pada periode penelitian dan bersedia menjadi responden. Variabel terikat yaitu obesitas dan variabel bebas yaitu pengetahuan gizi, kebiasaan makan fast food dan aktivitas fisik.

Data yang dikumpulkan meliputi data obesitas, pengetahuan gizi, kebiasaan makan fast food, dan aktivitas fisik responden. Data lain yang dikumpulkan yaitu data karakteristik individu (umur, jenis kelamin, uang saku). Data obesitas dikumpulkan melalui pengukuran berat badan dan tinggi badan siswa. Berat badan siswa diukur menggunakan timbangan berat badan yang telah dikalibrasi dan memiliki ketelititian $0.1 \mathrm{Kg}$. Tinggi badan diukur menggunakan alat ukur tinggi badan microtoise yang memiliki ketelitian $0.1 \mathrm{~cm}$. Hasil pengukuran diterjemahkan ke dalam indeks massa tubuh menurut umur (IMT/U), yaitu membagi berat badan dalam kilogram dengan tinggi badan anak dalam meter persegi $\left(\mathrm{kg} / \mathrm{m}^{2}\right)$. IMT/U dikelompokkan menjadi dua yaitu obesitas dan tidak obesitas. Obesitas bila nilai Z-score IMT/U lebih dari $2 \mathrm{SD}$, tidak obesitas bila Z-score IMT/U kurang dari atau sama dengan $2 \mathrm{SD}^{12}$.

Pengetahuan gizi diukur dengan 20 pertanyaan tentang gizi, melalui angket. Penilaian pengetahuan gizi dilakukan dengan memberi skor 0 bila jawaban salah dan skor 1 bila jawaban benar, sehingga skor total minimum 0 dan maksimum adalah 20 . Kategori pengetahuan gizi dikelompokkan menjadi dua, yaitu kategori pengetahuan gizi rendah bila skor $<80.0 \%$, kategori pengetahuan gizi tinggi bila skor $\geq 80.0 \%$. Berdasarkan kuesioner Khomsan ${ }^{13}$, kebiasaan makan fast food diukur menggunakan food frequency questionnaire (FFQ) yang diisi sendiri oleh siswa. FFQ berisi jenis makanan dan frekuensi mengonsumsi dalam seminggu. Jenis makanan yang ditanyakan yaitu fried chiken, chiken nugget, hot dog, hamburger, sphagetti, donat, kentang goreng. Frekuensi konsumsi dikelompokkan menjadi dua yaitu sering (lebih dari 2 kali per minggu) dan jarang (kurang dari atau sama dengan 2 kali per minggu).

Aktivitas fisik diukur menggunakan kuesioner Baecke yang membagi aktivitas fisik ke dalam 3 domain yaitu aktivitas sehari-hari, aktivitas olah raga dan aktivitas waktu senggang. Indeks Aktivitas Fisik merupakan penjumahan indeks aktivitas sehari-hari ditambah indeks aktivitas olah raga dan aktivitas senggang. Hasil penjumlahan dikelompokkan ke dalam 2 kelompok yaitu aktivitas fisik (AF) kurang 
Sugiatmi dan Dian Rini Handayani, Faktor Dominan Obesitas pada Siswa Sekolah Menengah Atas di Tangerang Selatan Indonesia

DOI : $10.24853 /$ jkk.14.1.1-10

(skor AF kurang dari 5.6) dan cukup (skor AF sama dengan atau lebih dari 5.6). Manajemen data meliputi entry, edit dan cleaning data. Analisis data menggunakan piranti lunak meliputi analisis univariat dan bivariat (uji chi square).

\section{Hasil}

Hasil distribusi frekuensi obesitas menunjukkan proporsi obesitas pada siswa SMA sebesar $42.7 \%$ dan tidak obesitas sebesar $57.3 \%$.

Tabel 1. Distribusi Frekuensi Responden Berdasarkan Status Obesitas

\begin{tabular}{lcc}
\hline Obesitas & n & \% \\
\hline Ya & 56 & 42.7 \\
Tidak & 75 & 57.3 \\
& & \\
\hline Total & 131 & 100
\end{tabular}

Tabel 2 merupakan hasil analisis bivariat mengenai hubungan karakteristik siswa dengan obesitas. Hasil analisis tersebut menunjukkan bahwa jenis kelamin dan umur tidak berhubungan dengan kejadian obesitas, sedangkan pengetahuan gizi, kebiasaan konsumsi fast food dan aktivitas fisik memiliki hubungan yang signifikan. Hal ini dibuktikan dengan nilai $p$ value pada jenis kelamin dan umur lebih dari 0.05 ( $>>0.05$ ) yaitu 0.543 dan 0.051. Pada variabel pengetahuan gizi, siswa yang memiliki pengetahuan gizi rendah berisiko 2.8 kali lebih besar mengalami obesitas dibanding siswa yang mempunyai pengetahuan gizi tinggi $(\mathrm{OR}=2.894 ; 95 \%$ $\mathrm{CI}=1.342$ - 6.242). Siswa yang memiliki kebiasaan sering mengkonsumsi fast food berisiko 2.7 kali lebih besar mengalami obesitas (OR=2.743; 95\% CI=1.271 - 5.919) dibanding siswa yang jarang mengkonsumsi fast food. Pada aktivitas fisik, siswa dengan aktivitas fisik yang kurang $(\mathrm{OR}=2.386$, 95\% CI=1.105 - 5.153) berisiko 2.3 kali lipat memiliki risiko obesitas dibanding siswa yang memiliki aktivitas fisik cukup.

Variabel pada Tabel 2 yang memiliki nilai $\mathrm{p}$ kurang dari 0.05 (pvalue $=$ $<0.05$ ) hanya pada variabel pengetahuan gizi, kebiasaan konsumsi fast food dan aktivitas fisik sehingga hanya 3 variabel tersebut yang disertakan ke dalam analisis logistik ganda. Hasil uji logistik ganda ditunjukkan pada Tabel 3 yaitu diperoleh 2 variabel yang dominan yaitu pengetahuan gizi dan kebiasaan konsumsi fast food. Hasil analisis statistik menunjukkan bahwa siswa yang memiliki pengetahuan gizi rendah berisiko obesitas 2.8 kali dibandingkan dengan siswa yang memiliki pengetahuan gizi tinggi $(\mathrm{OR}=2.883,95 \% \mathrm{CI}=1.312$ 6.334), sedangkan siswa yang sering mengkonsumsi fast food berisiko obesitas sebesar 2.7 kali $(\mathrm{OR}=2.731,95 \% \mathrm{CI}=1.240$ - 6.018) dibandingkan dengan siswa yang jarang mengkonsumsi fast food. 
Tabel 2. Hubungan Karakteristik Siswa SMA dengan Obesitas

\begin{tabular}{|c|c|c|c|c|c|c|c|c|}
\hline \multirow{3}{*}{ Karakteristik Siswa } & \multicolumn{4}{|c|}{ Obesitas } & \multirow{3}{*}{ P value } & \multirow{3}{*}{ OR } & \multicolumn{2}{|c|}{$95 \% \mathrm{CI}$} \\
\hline & \multicolumn{2}{|c|}{ Ya } & \multicolumn{2}{|c|}{ Tidak } & & & $\mathbf{I}$ & $\mathbf{U}$ \\
\hline & $\mathbf{n}$ & $\%$ & $\mathbf{n}$ & $\%$ & & & Lower & Upper \\
\hline \multicolumn{9}{|l|}{ Jenis Kelamin } \\
\hline Laki-laki & 20 & 46.5 & 23 & 53.5 & 0.543 & & & \\
\hline Perempuan & 36 & 409 & 52 & 59.1 & & & & \\
\hline \multicolumn{9}{|l|}{ Umur (tahun) } \\
\hline 15 & 6 & 75.0 & 2 & 25.0 & 0.051 & & & \\
\hline 16 & 33 & 36.7 & 57 & 63.3 & & & & \\
\hline 17 & 13 & 36.4 & 15 & 53.6 & & & & \\
\hline 18 & 4 & 80.0 & 1 & 20.0 & & & & \\
\hline \multicolumn{9}{|l|}{ Pengetahuan Gizi } \\
\hline Rendah & 43 & 51.8 & 40 & 48.2 & $0.006 *$ & 2.894 & 1.342 & 6.242 \\
\hline Tinggi & 13 & 27.1 & 35 & 72.9 & & & & \\
\hline \multicolumn{9}{|l|}{ Kebiasaan Konsumsi } \\
\hline \multicolumn{9}{|l|}{ Fast Food } \\
\hline Sering & 43 & 51.2 & 41 & 48.8 & $0.009 *$ & 2.743 & 1.271 & 5.919 \\
\hline Jarang & 13 & 27.7 & 34 & 72.3 & & & & \\
\hline \multicolumn{9}{|l|}{ Aktivitas Fisik } \\
\hline Kurang & 22 & 57.9 & 16 & 42.1 & $0.025 *$ & 2.386 & 1.105 & 5.153 \\
\hline Cukup & 34 & 36.6 & 59 & 63.4 & & & & \\
\hline
\end{tabular}

Tabel 3. Analisis Multivariat Obesitas pada Siswa SMA

\begin{tabular}{lcccccc}
\hline \multicolumn{1}{c}{ Variabel } & B & Wald & P Value & OR & \multicolumn{2}{c}{ 95\% CI } \\
\cline { 5 - 7 } & & & & & Lower & Upper \\
\hline Kebiasaan Konsumsi Fast Food & 1.005 & 6.215 & 0.013 & 2.731 & 1.240 & 6.018 \\
Pengetahuan Gizi & 1.059 & 6.950 & 0.008 & 2.883 & 1.312 & 6.334 \\
Konstanta & -2.437 & 9.860 & 0.002 & 0.084 & & \\
\hline
\end{tabular}

\section{Pembahasan}

Analisis univariat obesitas menunjukkan proporsi obesitas pada siswa SMA sebesar $42.7 \%$ dan tidak obesitas sebesar 57.3\% (Tabel 1). Hasil ini cukup tinggi jika dibandingkan dengan penelitian sejenis $^{14}$ pada Remaja SMA Negeri 9 Semarang sebesar $8.75 \%$ yang mengalami obesitas. Sementara penelitian ${ }^{15}$ pada siswa SMA di Kota Banda Aceh, prevalensi yang mengalami obesitas hanya $2.7 \%$. Terjadinya perbedaan hasil pada penelitian ini dengan penelitian sebelumnya dimungkinkan karena perbedaan karakteristik responden, jumlah sampel, dan metode pengambilan sampel penelitian. Kurang beragamnya sampel juga dimungkinkan menjadi penyebab hasil yang berbeda pada penelitian ini.

Berdasarkan karakteristik siswa, obesitas pada siswa perempuan lebih banyak dibanding siswa laki-laki. Berdasarkan umur, proporsi siswa obesitas lebih banyak terdapat pada siswa umur 15 dan 18 tahun (Tabel 2). Hal ini disebabkan, remaja perempuan lebih banyak menyimpan kelebihan energinya sebagai lemak 
Sugiatmi dan Dian Rini Handayani, Faktor Dominan Obesitas pada Siswa Sekolah Menengah Atas di Tangerang Selatan Indonesia

DOI : $10.24853 /$ jkk.14.1.1-10

simpanan sedangkan remaja laki-laki hanya menggunakan kelebihan energinya untuk mensintesis protein. Pada saat kematangan fisik terjadi, umumnya jumlah lemak tubuh pada remaja perempuan dua kali lebih banyak dibanding laki-laki dalam rangka mempersiapkan kehamilan, sehingga perempuan memiliki kecenderungan mengalami gizi lebih. Hal ini sejalan dengan penelitian ${ }^{16}$, yang menyebutkan bahwa remaja perempuan memiliki kecenderungan lebih besar untuk mengalami gizi lebih (IMT tinggi) dibandingkan remaja laki-laki.

Pada tabel 2 dapat dilihat pula bahwa proporsi obesitas lebih tinggi pada siswa yang berpengetahuan gizi rendah dan sering mengkonsumsi fast food. Hal ini disebabkan, remaja dengan pengetahuan gizi yang baik dapat mengetahui zat gizi yang dibutuhkan oleh tubuh dan menghindari makanan yang memberikan dampak buruk bagi dirinya. Hal ini sesuai dengan penelitian yang menyebutkan banyak sedikitnya informasi dan kemampuan yang dimiliki seseorang mengenai kebutuhan tubuhnya untuk menerapkan pengetahuan gizi kedalam memilih makanan yang akan dimakan, sangat mempengaruhi jumlah dan jenis makanan yang di konsumsi ${ }^{17}$. Proporsi obesitas pada siswa yang sering mengkonsumsi fast food lebih tinggi, jelas disebabkan menu makanan fast food merupakan menu makanan yang tinggi akan kalori, garam dan kadar lemak. Konsumsi fast food dapat menyebabkan berbagai penyakit salah satunya obesitas, hal ini sejalan dengan penelitian yang menyebutkan bahwa efek negatif yang dikaitkan dengan konsumsi makanan cepat saji, mulai dari kenaikan berat badan hingga peningkatan risiko diabetes ${ }^{18}$.

Dari hasil penelitian, didapatkan bahwa proporsi obesitas juga tinggi pada siswa yang melakukan aktivitas fisik kurang. Ada banyak hal yang menyebabkan siswa kurang melakukan aktivitas fisik. Salah satunya dikarenakan rata-rata siswa lebih memilih diantar jemput oleh orang tuanya menggunakan kendaraan dibanding berjalan kaki yang lebih banyak menggunakan energi. Hal tersebut disebabkan jarak tempuh dari rumah ke sekolah yang cukup menghabiskan waktu jika dilakukan dengan berjalan kaki, sehingga siswa memilih menggunakan alat transportasi. Rendahnya aktivitas fisik seperti berjalan kaki tersebut menyebabkan asupan energi yang dihasilkan tidak banyak digunakan sehingga sebagian besar tersimpan sebagai lemak tubuh ${ }^{19}$.

Hasil analisis bivariat dari enam variabel yang diteliti, terdapat tiga variabel yang terbukti berhubungan dengan kejadian obesitas (Tabel 2). Pengetahuan gizi berhubungan secara bermakna dengan kejadian obesitas $(\mathrm{p}<0.05)$. Siswa yang memiliki pengetahuan gizi rendah akan berisiko obesitas 2.89 kali untuk menderita obesitas. Dari hasil uji menggambarkan bahwa siswa dengan tingkat pengetahuan yang rendah, tidak dapat mengenali faktor- 
faktor yang kemungkinan dapat menyebabkan obesitas dan dampak yang akan terjadi bila mengalami obesitas dan begitu sebaliknya ${ }^{17}$.

Obesitas berhubungan pula secara bermakna $\quad(p<0.05)$ pada siswa yang memiliki kebiassan konsumsi fast food sering $(\mathrm{OR}=2.74)$ dan beraktivitas fisik kurang $(\mathrm{OR}=2.39)$. Siswa yang sering mengonsumsi fast food berisiko 2.74 kali untuk obesitas dibanding siswa yang jarang mengonsumsi fast food. Siswa yang memiliki aktivitas fisik kurang berisiko 2.39 kali untuk obesitas dibanding siswa yang memiliki aktivitas fisik cukup. Hasil penelitian tersebut sejalan dengan penelitian $^{19}$ menyatakan bahwa ada hubungan yang signifikan antara aktivitas fisik dengan kejadian obesitas $(\mathrm{p}=0.01)$. Penelitian serupa juga ${ }^{20}$ menyatakan bahwa ada hubungan yang signifikan antara aktivitas fisik dengan kejadian obesitas $(\mathrm{p}=0.000)$ dan penelitian ${ }^{21}$ dengan hasil uji ada hubungan yang signifikan antara aktivitas fisik dengan kejadian obesitas $(\mathrm{p}=0.00)$. Terjadinya obesitas dikarenakan rendahnya aktivitas fisik yang dilakukan siswa sehingga asupan energi yang masuk ke dalam tubuh hanya sedikit terpakai untuk beraktivitas dan sebagian besar tersimpan sebagai lemak tubuh, dengan kata lain kelompok obesitas hanya menggunakan sedikit energi untuk melakukan aktivitasnya ${ }^{20}$. Namun hasil penelitian ini tidak sejalan dengan penelitian $^{22}$ yang menyatakan bahwa tidak ada hubungan antara aktivitas fisik dengan kejadian obesitas $(\mathrm{p}=0.481)$.

Berdasarkan Tabel 3 hasil analisis multivariat diperoleh dua variabel yang berhubungan bermakna dengan risiko obesitas yaitu kebiassan konsumsi fast food dan pengetahuan gizi $(\mathrm{p}<0.05)$. Variabel yang paling dominan berhubungan dengan obesitas yaitu pengetahuan gizi siswa dengan nilai OR yang paling besar yaitu 2.8, artinya bahwa siswa yang memiliki pengetahuan gizi rendah berisiko obesitas 2.8 kali lebih besar dibanding siswa yang memiliki pengetahuan gizi tinggi. Siswa dengan pengetahuan gizi yang tinggi telah mengetahui adanya risiko gizi lebih atau obesitas, sehingga siswa dapat menjaga pola makan dan aktifitas fisik ${ }^{14}$. Tetapi hal tersebut dapat diduga berlebihan dalam hal mengkonsumsi makanan. Keinginan siswa untuk dapat memenuhi gizi seimbang diduga tidak dibarengi dengan jumlah dan porsi makan yang seimbang pula, sehingga menyebabkan terjadinya gizi lebih atau obesitas.

\section{Kesimpulan dan Saran}

Faktor dominan obesitas pada siswa SMA di Tangerang Selatan adalah pengetahuan tentang gizi dan kebiasaan konsumsi fast food. Pihak sekolah dapat menjadikan penelitian ini sebagai acuan dalam membuat kebijakan mengenai upaya pencegahan obesitas dan pendidikan 
Sugiatmi dan Dian Rini Handayani, Faktor Dominan Obesitas pada Siswa Sekolah Menengah Atas di Tangerang Selatan Indonesia

mengenai gizi di sekolah. Salah satu upaya yang dapat dilakukan adalah melakukan pelatihan tentang gizi dan makanan sehat secara teratur kepada siswa. Pendekatan dapat memanfaatkan media teknologi yang sesuai dengan perkembangan zaman, serta mengintegrasikan pengetahuan gizi ke dalam kurikulum sekolah untuk meningkatkan pengetahuan gizi siswa.

\section{Daftar Pustaka}

1. World Health Organization. Obesity and overweight [Internet]. 2017. Available from: http://www.who.int/mediacentre/fact sheets/fs311/en/

2. WHO. Obesity and Overweight. Glob Strateg Diet, Phys Act Heal. 2003;1-2.

3. Ogden CL, Carroll MD, Fryar CD, Flegal KM. Prevalence of Obesity Among Adults and Youth: United States, 2011-2014. Natl Cent Heal Stat. 2015;(219):2011-4.

4. Restuastuti T, Jihadi M, Ernalia Y. Hubungan Pola Makan dan Aktivitas Fisik terhadap Obesitas pada Remaja di SMA Negeri 5 Pekanbaru. J Online Mhs Fak Kedokt Univ Riau. 2016;3(1):1-20.

5. Zametkin AJ, Zoon CK, Klein HW, Munson S. Psychiatric Aspects of Child and Adolescent Obesity: A Review of the Past 10 Years. J Am Acad Child Adolesc [Internet].
2004;43(2):134-50. Available from: http://www.jaacap.com/article/S089 0-8567(09)61269-7/fulltext

6. Badan Penelitian dan Pengembangan Kesehatan Republik Indonesia. Riset Kesehatan Dasar (RISKESDAS) 2013. Badan Penelitian dan Pengembangan Kesehatan Kementerian Kesehatan RI. 2013.

7. Arisman. Gizi dalam Daur Kehidupan. EGC; 2014.

8. Indriawati R, Soraya F. Hubungan Konsumsi Makanan Cepat Saji dan Tingkat Aktivitas Fisik terhadap Obesitas pada Kelompok Usia 11-13 Tahun The Correlation Between Fast Food Consumption and Level of Physical. Mutiara Med. 2009;9(2):123-8.

9. Khomsan A. Pangan dan Gizi Untuk Kesehatan. Raja Grafindo Persada (Rajawali Pers); 2010.

10. Harrison MM, Morrel J, Hopman WM. Influence of obesity on outcome after knee arthroscopy. Arthrosc J Arthrosc Relat Surg [Internet]. 2004;20(7):691-5. Available from: https://www.sciencedirect.com/scien ce/article/pii/S0749806304005894

11. World Health Organization. Maternal, newborn, child and adolescent health [Internet]. [cited 2018 Jan 22]. Available from: http://www.who.int/maternal_child_ 
adolescent/topics/adolescence/devel opment/en/

12. Kementerian Kesehatan RI. Standar Antropometri Penilaian Status Gizi Anak. 2010. p. 40.

13. Khomsan A. Peranan Pangan dan Gizi Untuk Kualitas Hidup. Jakarta: PT. Rajagrafindo Persada; 2012.

14. Dwi Oktaviani W, Dian Saraswati L, Zen Rahfiludin M, Fkm Undip A, Bagian Epidemiologi dan Penyakit Tropik FKM UNDIP D, Bagian Gizi FKM UNDIP D. Hubungan Kebiasaan Konsumsi Fast Food, Aktivitas Fisik, Pola Konsumsi, Karakteristik Remaja dan Orang Tua dengan Indeks Massa Tubuh (IMT) (Studi Kasus pada Siswa SMA Negeri 9 Semarang Tahun 2012). 2012;1(2):542-53.

15. Wilujengl LK. Banda Aceh Provinsi Nanggroe Aceh Darussalam. 2003;

16. Manurung NK. Pengaruh Karakteristik Remaja, Genetik, Pendapatan keluarga, Pendidikan Ibu, Pola Makan dan Aktivitas Fisik terhadap Kejadian Obesitas di SMU RK TRi Sakti Medan 2008. Tesis. Sekolah Pascasarjana Universitas Sumatera Utara Medan. 2009.

17. Bantarpraci S. Hubungan Karakteristik Individu, Aktivitas Fisik, Asupan Zat Gizi Makro (Asupan Energi, Protein, Lemak, dan Karbohidrat) dengan Obesitas di
Kementerian Koperasi dan Usaha Kecil Menengah Tahun 2012. 2012;

18. Sharifirad G, Yarmohammadi P, Azadbakht L, Morowatisharifabad MA, Hassanzadeh A. Determinants of fast food consumption among iranian high school students based on planned behavior theory. J Obes. 2013;2013:147589.

19. Candra A, Wahyuni TD, Sutriningsih A. Hubungan Antara Aktivitas Fisik dan Pola Makan dengan Kejadian Obesitas pada Remaja di SMA Laboratorium Malang. Nurs News J Ilm Mhs Keperawatan. 2016 Jul;1(1).

20. Musralianti F, Rattu AJM, Kaunang WPJ, Kesehatan F, Universitas M, Ratulangi S. Hubungan Antara Aktivitas Fisik dan Pola Makan dengan Kejadian Obesitas Pada Siswa di SMP Kristen Eben Haezar 1 Manado. PHARMACON J Ilm Farm - UNSRAT. 2016;5(2).

21. Herlina O:, Se M, Kes. Hubungan Aktivitas Fisik Remaja dengan Kejadian Obesitas di SMKN 1 Sibolga Tahun 2012. J Maret. 2016;22(1).

22. Sudikno, Herdayati M, Besral. Hubungan Aktivitas Fisik dengan Kejadian Obesitas pada Orang Dewasa di Indonesia. Gizi Indones. 2010;33(1):37-49. 